\title{
Peningkatan Kualitas Pembelajaran IPA Melalui Model Pembelajaran Problem Based Instruction (PBI) dengan Media Kartu Pintar pada Siswa Kelas III SD Negeri 64/IV Kota Jambi Semester Genap Tahun Pelajaran 2017/2018
}

\author{
Yuslolita \\ Guru SD Negeri 64/IV Kota Jambi \\ Email: yusjambi@yahoo.com
}

\begin{abstract}
Background problems in science learning, teachers do not involve students in investigations, students are less trained in developing work (products). The concepts mastered by students are only given by rote by the teacher, students are not taught through a process of discovery that is problem-oriented in everyday life. Based on these problems, the most appropriate solution is to implement the PBI model with smart card media. The general problem formulation is how to improve the quality of science learning in class III 64 / IV SD Negeri Jambi. Whereas specifically is whether through the Problem Based Instruction learning model with smart card media can improve teacher skills, student activities, and student learning outcomes in class III science learning at SD Negeri 64 / IV Jambi City. The general objective of this study was to improve the quality of science learning in third grade students of SD Neegri 64 / IV Jambi City. Specifically, it is to improve teacher skills, student activity, and learning outcomes in class III 64th Natural Science learning. This type of research is classroom action research, using the Problem Based Instruction model with smart card media that is applied in three cycles. Each cycle consists of two cycles with four meetings and four stages, namely planning, implementation, observation, and reflection. Subjects of the study were third grade students of SD Neegri 64 / IV Jambi City even semester 2017/2018. Data collection techniques used tests to measure learning outcomes and student activities using instruments, and observation formats for teacher management in classroom learning. The results of the study showed that for the management of learning in the classroom in cycle 1 was a score of 32, cycle 2 received a score of 38 and cycle 3 obtained a score of 48 with good criteria. The results of the study The activities of students obtain an average score of two meetings in cycle 1 is 25.85 with sufficient criteria; The cycle obtained a score of 45 with good criteria. In cycle 3, the score obtained was 34.25 in the good category. While for student learning outcomes the average percentage of classical completeness from the two meetings in cycle 1 was $56.41 \%$. Cycle 2 obtained the percentage of classical completeness was $64 \%$. In cycle 3 , the percentage of classical completeness was $82 \%$. The results of this study have shown that the indicators of success have been achieved so that this study was declared successful. As for the conclusions of this study, through the Problem Based Instruction (PBI) model with smart card media can improve teacher learning management, student activities and learning outcomes of class III SD Neegri 64 / IV Jambi City at even semester 2017/2018 school year.
\end{abstract}

Keywords: Problem Based Instruction (PBI) Model, Learning Quality, Smart Card Media.

\section{PENDAHULUAN}

Sistem Pendidikan Nasional di Indonesia beserta berbagai Peraturan Pemerintah (PP) yang berkenaan dengan pendidikan tercantum dalam Undang- Undang RI Nomor 20 Tahun 2003 (BSNP, 2007: 2). Dijelaskan bahwa kurikulum pendidikan dasar dan menengah dikembangkan sesuai dengan relevansinya oleh setiap kelompok atau satuan pendidikan dan komite sekolah/madrasah dibawah koordinasi dan supervisi dinas pendidikan dan kantor Departemen Agama Kabupaten/Kota untuk pendidikan dasar dan pendidikan menengah. Fungsi pendidikan nasional adalah mengembangkan kemampuan dan membentuk watak serta peradaban bangsa yang bermatabat dalam rangka mencerdaskan kehidupan bangsa.

Standar kompetensi dan kompetensi dasar SD/MI yang tercantum dalam Peraturan Menteri Pendidikan Nasional Nomor 22 Tahun 2006 (Permendiknas, 2006) tentang standar isi untuk satuan pendidikan dasar dan menengah menyebutkan bahwa perkembangan IPA tidak hanya ditandai oleh adanya kumpulan fakta saja, tetapi juga ditandai oleh munculnya "metode ilmiah" (scientific methods) yang terwujud melalui suatu rangkaian"kerja ilmiah" (working scientifically), nilai dan "sikap ilmiah" (scientific attitudes). Pendidikan IPA diharapkan dapat menjadi wahana bagi peserta didik untuk mempelajari dirisendiri dan alam sekitar serta prospek pengembangan lebih lanjut dalam menerapkannya dalam kehidupan sehari-hari.

Setelah dikaji mengenai standar isi untuk pendidikan dasar dan menengah, pelaksanaan proses belajar yang diharapkan yaitu sesuai dengan Permendiknas Nomor 41 Tahun 2007 (Permendiknas, 2007) mengenai standar proses yang mencakup perencanaan proses pembelajaran, pelaksanaan proses pembelajaran, penilaian hasil pembelajaran, dan pengawasan proses pembelajaran untuk ter- laksananya proses pembelajaran yang efektif dan efisien. Tentunya tanpa meninggalkan proses pembelajaran pada setiap satuan pendidikan dasar dan menengah yang mengedepankan interaksi, inspiratif, menyenangkan, menantang, memotivasi keaktifan partisipasi, ruang lega untuk berkreasi, memunculkan ide gagasan yang original selaras dengan bakat, minat, fisik dan suasana psikologi peserta didik.

Tujuan yang tercantum dalam KTSP sudah baik ditunjukkan dengan berbagai teori yang mendukung yaitu tercantum dalam KTSP tahun 2006 seperti dijelaskan di atas yakni dengan mengandung ide-ide yang dapat mengantisipasi perkembangan IPTEK secara global. Namun kenyataannya di sekolah-sekolah masih perlu peningkatan kualitas pembelajaran.Menurut pengamatan peneliti, hal tersebut dikarenakan guru dan siswa masih belum inovatif selama pembelajaran. Hal tersebut sesuai dengan hasil penelitian sains pada tingkat Internasional yang diselengarakan oleh Organization for Economic Co-operation and Development (OECD) untuk anak usia 15 tahun, yang telah dua periode diselenggarakan, Indonesia ikut berpartisipasi dalam kedua penelitian tersebut. Pertama, 
tahun 2000 diikuti oleh 41 negara, Indonesia berada pada urutan ke-38 pada kemampuan sains. Kedua, tahun 2003 diikuti oleh 40 negara, Indonesia berada pada urutanke-38 pada kemampuan sains.Dari uraian di atas jelaslah bahwa pembelajaran IPA yang terlaksana di sekolah-sekolah harus terus dikaji, dikembangkan sehingga menghasilkan pembelajaran yang betul-betul tepat dengan tuntutan dan perkembangan zaman serta dapat dipahami oleh para pelaku pendidikan untuk diterapkan pada situasi sesungguhnya.

Dari beberapa uraian kendala yang ditemukan observer dalam pembelajaran IPA di SD Negeri 64/IV Kota Jambi, diperkuat dengan adanya data kuantitatif yang masih banyak siswa mendapat nilai di bawah Kriteria Ketuntasan Minimal (KKM) yaitu 70. Data hasil belajar siswa menunjukkan dari 37 siswa kelas III, yang mendapat nilai memenuhi KKM yaitu 17 (46\%) siswa, sedangkan 20 (54\%) siswa mendapat nilai dibawah KKM. Dari data yang diperoleh tersebut, perlu adanya upaya untuk meningkatkan kualitas pembelajaran IPA agar pembelajaran lebih bermakna.Hal itu, dapat dilakukan dengan diawali adanya peningkatan pada pengelolaan pembelajaran guru yang dapat memicu motivasi dalam belajar, dapat diupayakan dengan mengembangkan model-model pembelajaran inovatif dan menekankan keterampilan dasar mengajar guru.Sehingga, dapat memicu aktivitas siswa dalam pembelajaran IPA yang pada akhirnya dapat meningkatkan hasil belajar siswa.

Untuk meminimalisir berbagai kendala yang terdapat dalam pembelajaran IPA diperlukan penerapan model pembelajaran inovatif yang diharapkan dapat meningkatkan kualitas pembelajaran yang meliputi keterampilan guru, aktivitas siswa, dan hasil belajar.Pembelajaran inovatif mengutamakan peran guru sebagai fasilitator, evaluator, motivator, dan informator.Sehingga siswa belajar dengan penyelidikan dan dapat memecahkan masalah melalui pengetahuannya dan interaksi dengan lingkungan sebagai sumber belajar. Salah satu model pembelajaran inovatif yang dapat meminimalisir masalah tersebut di atas adalah dengan menerapkan model Problem Based Instruction. Menurut Arends (2008: 43), Problem Based Intruction merupakan suatu model pembelajaran yang melibatkan presentasi situasi-situasi yang autentik dan bermakna, yang berfungsi sebagai landasan bagi investigasi dan penyelidikan siswa. Sehingga, dengan menerapkan model Problem Based Instruction pada pembelajaran IPA, maka kerja ilmiah pun menjadi terdukung. Karena, model Problem Based Instruction menuntut siswa untuk berpikir kritis dengan melakukan berbagai penyelidikan yang berorientasi pada permasalahan autentik guna pemecahan masalah. Dengan demikian, melalui PBI siswa terlatih untuk dapat menemukan sendiri berbagai konsep yang dipelajari secara holistik, bermakna, autentik, dan aktif, memecahkan sendiri masalah-masalah dari suatu konsep yang dipelajari, sedangkan guru lebih banyak bertindak sebagai motivator dan fasilitator. Situasi belajar yang diharapkan di sini adalah siswa yang lebih banyak berperan (kreatif).Prinsip penggunaan model pembelajaran inovatif Problem Based Instruction adalah siswa lebih terlatih untuk memecahkan masalah dan berpikirkritis.

Dari hasil penelitian di atas dapat digunakan sebagai pendukung pelaksanaan tindakan yang akan peneliti laksanakan dengan menerapkan model pembelajaran Problem Based Instruction. Oleh karena itu perlu dilaksanakan penelitian tindakan kelas untuk memperbaiki dan meningkatkan kualitas pembelajaran IPA di SD Negeri 64/IV Kota Jambi.

\section{Kajian Teori \\ Hakikat Belajar}

Belajar merupakan sebuah sistem yang di dalamnya terdapat berbagai unsur yang saling terkait sehingga akan terjadi perubahan perilaku. Karena hasil dari kegiatan belajar dapat dinilai dari perubahan perilaku seseorang.Berikut beberapa pengertian belajar. Menurut Rifa"I dan Anni, (2009: 82) belajar merupakan proses dimana suatu organisme mengubah perilakunya karena hasil daripengalaman.

Sedangkan menurut Hamalik (2008:27) belajar adalah modifikasi atau memperteguh kelakuan melalui pengalaman (learning is defined as the modification or strengthening of behavior through experiencing). Menurut pengertian ini, belajar merupakan suatu proses, suatu kegiatan dan bukan suatu hasil atau tujuan.

Berdasarkan pendapat ahli di atas mengenai pengertian belajar, dapat disimpulkan belajar merupakan

a) Berkaitan dengan perubahanperilaku.

Perilaku yang tampak (overt behaviour) seperti berbicara, menulis puisi, mengerjakan penyelidikan dapat memberi pemahaman tentang perubahan perilakuseseorang.Untuk mengukur apakah seseorang telah belajar atau belum belajar diperlukan adanya perbandingan antara perilaku sebelum dan setelah mengalami kegiatan belajar.

b) Perubahan perilaku terjadi karena didahului oleh prosespengalaman.

Pengalaman yang dimaksud dapat dapat berupa pengalaman fisik, psikis, dan sosial.Perubahan perilaku dapat terjadi karena pertumbuhan dan kematangan fisik, seperti tinggi dan berat badan, dan kekuatan fisik, tidak dapat dipandang sebagai hasil belajar.

c) Perubahan perilaku karena belajar bersifat relatifpermanen.

Apabila seseorang mampu memahami proses belajar dan menerapkan pengetahuan yang diperoleh dari belajar pada kehidupan nyata maka seseorang akan mampu menjelaskan segala sesuatu yang ada dilingkungannya.

\section{Faktor-Faktor Yang Mempengaruhi Belajar}

Kegiatan belajar juga terdapat beberapa faktor yang mempengaruhi, sehingga kegiatan belajar akan terdukung. Beberapa faktor yang mempengaruhi belajar diantaranya menurut pendapat Anni (2006: 97) faktorfaktor yang mempengaruhi belajar adalah kondisi internal dan eksternal.Kondisi internal mencakup kondisi fisik, seperti kesehatan organ tubuh, kondisi psikis, seperti kemampuan intelektual, emosional, dan kondisi 
sosial, seperti kemampuan bersosialisasi dengan lingkungan. Beberapa faktor eksternal antara lain variasi dan derajat kesulitan materi (stimulus) yang dipelajari (direspon), tempat belajar, iklim, suasana, lingkungan, dan budaya belajar masyarakat akan mempengaruhi kesiapan, proses, dan hasilbelajar.

Pendapat lain diutarakan oleh Hamalik (2008: 32) yang menyatakan faktor-faktor belajar adalah sebagai berikut: 1) faktor kegiatan, penggunaan, dan ulangan; 2) belajar memerlukan latihan, dengan jalan: relearning, recalling,danreviewing; 3) belajar siswa lebih berhasil jika siswa merasa berhasil dan kepuasan; 4) siswa yang belajar perlu mengetahui apakah dia berhasil atau gagal; 5) faktor asosiasi; 6) pengalaman masa lampau dan pengertian-pengertian yang sudah dimiliki oleh siswa; 7) faktor kesiapan belajar; 8) faktor minat dan usaha; 9) faktor fisiologis; 10) faktor intelegensi.

\section{Hakikat Pembelajaran}

Pembelajaran merupakan terjemahan dari learning.Pembelajaran dapat diartikan sebagai proses dalam kegiatan belajar. Penggunaan model, metode, dan pendekatan dapat digunakan untuk tercapainya pembelajaran yang aktif dan menyenangkan. Pendapat Briggs (1992) pembelajaran adalah seperangkat peristiwa (events) yang mempengaruhi peserta didik sedemikian rupa sehingga peserta didik itu memperoleh kemudahan dalam berinteraksi berikutnya dengan lingkungan. Gagne (1981) menyatakan bahwa pembelajaran merupakan serangkaian peristiwa eksternal peserta didik yang dirancang untuk mendukung proses internal belajar (Rifa"I dan Anni, 2009: 192).

Pendapat mengenai pengertian pembelajaran juga diutarakan oleh Suprijono (2009:13) yang menyatakan bahwa pembelajaran merupakan suatu dialog interaktif yang terjadi antara guru dengan peserta didik. Pembelajaran berarti proses, cara, perbuatan mempelajari. Pembelajaran berpusat pada peserta didik sehingga dapat mengaktifkan siswa dalam pembelajarannya.

\section{Komponen-Komponen Pembelajaran}

Pembelajaran merupakan proses komunikasi yang terjalin antara pendidik dengan peserta didik, atau antar peserta didik yang bertujuan untuk membantu terlaksananya proses belajar, sedangkan komunikasi yang dilaksanakan dapat dilakukan dengan verbal atau secara lisan, dan secara nonverbal atau dengan bantuan media pembelajaran yang digunakan untuk membantu pembelajaran. Menurut Rifa"i dan Anni (2009: 194) pembelajaran bila ditinjau dari pendekatan sistem, maka dalam prosesnya akan melibatkan berbagai komponen. Komponen- komponen tersebut adalah sebagai berikut ;

a. Tujuan yang secara eksplisit diupayakan pencapaiannya melalui kegiatan pembelajaran yang biasanya berupa pengetahuan, dan keterampilan atau sikap yang dirumuskan.

b. Subyek belajar, yang dimaksud disini adalah peserta didik sebagai individu yang melakukan prosesbelajar.

c. Materi pengajaran merupakan salah satu komponen terpenting dalam proses pembelajaran, karena materi pengajaran akan memberi warna dan bentuk dari kegiatanpembelajaran

d. Strategi pembelajaran merupakan pola umum mewujudkan proses pembelajaran yang diyakini efektivitasnya untuk mencapai tujuan pembelajaran.

e. Media pembelajaran merupakan alat atau wahana yang digunakan pendidik dalam proses pembelajaran untuk membantu penyampaian pesan pembelajaran.

f. Penunjang yang dimaksud dalam sistem pembelajaran adalah fasilitas belajar, buku sumber, alat peraga, bahan pelajaran, dansemacamnya.

\section{Kualitas Pembelajaran}

Kualitas pembelajaran di sekolah dapat tercermin dari beberapa komponen, diantaranya dalam hal ini yaitu keterampilan guru yang dapat mengaktifkan siswanya dan menjadikan pembelajaran lebih bermakna, aktivitas siswa yang meningkat dalam pembelajaran, dan hasil belajar yang diperoleh siswa diatas KKM.Kualitas dapat diartikan dengan istilah mutu atau keefektifan yang secara definitif, efektivitas dapat dinyatakan sebagai tingkat keberhasilan dalam mencapai tujuan atau sasarannya. Efektivitas merupakan suatu konsep yang sangat penting karena mampu memberikan gambaran mengenai keberhasilan seseorang dalam mencapai sasaran atau tingkat pencapaian tujuan-tujuan Prokopenko (Hamdani, 2011: 194).

Penjelasan Depdiknas (2004: 7) tentang kualitas pembelajaran merupakan keterkaitan sistemik dan sinergis antara guru, siswa, kurikulum dan bahan belajar, media, fasilitas, dan sistem pembelajaran dalam menghasilkan proses dan hasil belajar yang optimal sesuai dengan tuntutan kurikuler. Indikator kualitas pembelajaran dapat dilihat antara lain dari perilaku pembelajaran pendidik, perilaku dan dampak belajar peserta didik, hasil belajar, iklim pembelajaran, materi pembelajaran, kualitas media pembelajaran.

\section{Keterampilan Guru}

Menurut Sudjana (1989: 31) bahwa tugas mengajar bukan pekerjaan yang sederhana melainkan memerlukan pemikiran dan tindakan yang mantap dari serangkaian kegiatan yang saling mengait dalam bentuk keutuhan. Rangkaian kegiatan tersebut dibagi menjadi tiga tahapan, yaitu tahap persiapan, pelaksanaan, dan evaluasi.

\section{Aktivitas Siswa}

Setiap siswa memiliki berbagai kebutuhan, meliputi kebutuhan jasmani, rohani dan sosial. Kebutuhan tersebut akan mendorong siswa untuk berbuat. Perbuatan-perbuatan yang dilakukan tersebut meliputi belajar dan bekerja yang bertujuan untuk memuaskan kebutuhan tertentu.Setiap waktu kebutuhan dapat berubah dan bertambah, sehingga menimbulkan variasi semakin banyak dan semakin luas. Dengan sendirinya perbuatan yang dilakukan akan semakin beraneka ragam (Hamalik, 2011: 171).

\section{Hasil Belajar}

Hasil belajar yang diperoleh siswa merupakan 
perubahan perilaku pada siswa setelah belajar.Hasil belajar dicerminkan bukan dari salah satu aspek potensi saja.Hasil belajar merupakan perubahan perilaku yang diperoleh peserta didik setelah mengalami kegiatan belajar Rifa"I dan Anni (2009: 85). Perolehan aspekaspek perubahan perilaku tersebut tergantung pada apa yang dipelajari oleh peserta didik. Oleh karena itu, apabila peserta didik mempelajari pengetahuan tetang konsep, maka perubahan perilaku yang diperoleh adalah berupa penguasaan konsep.

Penjelasan menurut Poerwanti, dkk (2008:1-23) yang menyatakan bahwa hasil belajar berdasarkan taksonomi Bloom (1956) menyampaikan tiga taksonomi yang disebut dengan ranah belajar, yaitu ranah kognitif (cognitive domain), ranah afektif (affective domain), dan ranah psikomotorik (psikomotoric domain)

\section{Hakikat Pembelajaran IPA di SD Pengertian IPA}

IImu Pengetahuan Alam (IPA) merupakan bagian dari IImu Pengetahuan atau Sains yang semula berasal dari bahasa Inggris science.Kata science sendiri berasal dari kata dalam bahasa Latin scientia yang berarti saya tahu.Science berasal dari social sciences (ilmu pengetahuan sosial) dan natural sciece (ilmu pengetahuan alam).Namun dalam perkembangannya science sering diterjemahkan sebagai sains yang berarti IImu Pengetahuan Alam (IPA) saja Suriasumantri (1998). Sedangkan menurut Wahyana (1986) mengatakan bahwa IPA adalah suatu kumpulan pengetahuan tersusun secara sistematik, dan dalam penggunaannya secara umum terbatas pada gejalagejala alam. Perkembangannya tidak hanya ditandai oleh adanya kumpulan fakta, tetapi oleh adanya metode ilmiah dan sikap ilmiah (Trianto, 2010: 136).

\section{Pembelajaran IPA di SD}

Pelaksanaan pembelajaran IPA dipengaruhi oleh tujuan apa yang ingin dicapai melalui pembelajaran tersebut. Tujuan pembelajaran IPA di SD telah dirumuskan dalam Kurikulum Tingkat Satuan Pendidikan (KTSP). Menurut Trianto (2010: 155) Standar Kompetensi dan Kompetensi Dasar yang akan dicapai peserta didik yang dituangkan dalam empat aspek, yaitu makhluk hidup dan proses kehidupan, materi dan sifatnya, energy dan perubahannya, serta bumi dan alam semesta. Indikator pencapaian kompetensi dikembangkan oleh sekolah, disesuaikan dengan lingkungan setempat, dan media serta lingkungan belajar yang ada di sekolah.Semua ini ditujukan agar guru lebih aktif, kreatif, dan melakukan inovasi dalam pembelajaran tanpa meninggalkan isi kurikulum.

Pembelajaran IPA di SD seharusnya disesuaikan dengan perkembangan kognitif anak.Teori Piaget (Slavin, 1994: 45) mencakup tahap sensorimotorik, preoperasional, dan operasional.Tahap sensorimotorik ( 0 - 2 tahun) pada tahap ini bayi menyusun pemahaman dunia dengan mengordinasikan pengalaman indera (sensori) mereka dengan gerakan motorik (otot) mereka. Preoperasional ( $2-7$ tahun) tahap ini pemikiran lebih bersifat simbolis, egoisentries, dan intuitif, sehingga tidak melibatkan pemikiran operasional. Tahap operasional konkrit (7-11 tahun) pada tahap ini anak mampu mengoperasionalkan berbagai logika, namun masih dalam bentuk benda konkrit.Tahap operasional formal ( 7 - 15 tahun) pada tahap ini anak sudah mampu berpikir abstrak, idealis, danlogis.

Sesuai dengan tahap perkembangan kognitif menurut Piaget, anak Sekolah Dasar berada pada tahap operasional konkrit.Pada tahap ini anak dapat mengoperasionalkan berbagai logika, namun masih dalam bentuk benda konkrit.

\section{Pengertian Problem Based Instruction sebagai Model Pembelajaran}

Model pembelajaran berbasis masalah merupakan model pembelajaran yang menggunakan permasalahan autentik dengan tujuan untuk menyusun pengetahuan siswa, mengembangkan inkuiri dan keterampilan tingkat tinggi. Pengertian pembelajaran berbasis masalah juga disampaikan oleh Rusman (2012: 229) pembelajaran berbasis masalah merupakan inovasi dalam pembelajaran karena dalam pembelajaran berbasis masalah kemampuan berpikir siswa betul- betul dioptimalisasikan melalui proses kerja kelompok atau tim yang sistematis, sehingga siswa dapat memberdayakan, mengasah, menguji, dan mengembangkan kemampuan berpikirnya secara berkesinambungan. Pembelajaran berbasis masalah adalah inovasi yang paling signifikan dalampendidikan.

\section{Teori Mendasari Model Problem Based Instruction}

Teori belajar yang menjadi landasan model pembelajaran berbasis masalah selain konstruktivisme, ada beberapa teori belajar lainnya yang melandasi model pembelajaran berbasis masalah, diantaranya teori dari Ausabel (dalam Rusman, 2012: 244) membedakan antara belajar bermakna (meaningfull learning) dengan belajar menghafal (rote learning). Belajar bermakna merupakan proses belajar di mana informasi baru dihubungkan dengan struktur pengertian yang sudah dimiliki seseorang yang sedang belajar. Belajar menghafal, diperlukan bila seseorang memperoleh informasi baru dalam pengetahuan yang sama sekali tidak berhubungan dengan yang telah diketahuinya. Kaitannya dengan Problem Based Instruction dalam hal mengaitkan informasi baru dengan struktur kognitif yang telah dimiliki oleh siswa.

Selain itu, menurut teori belajar Vigotsky, perkembangan intelektual terjadi pada saat individu berhadapan dengan pengalaman baru dan menantang serta ketika mereka berusaha untuk memecahkan masalah yang dimunculkan. Dalam upaya mendapatkan pemahaman, individu berusaha mengaitkan pengetahuan baru dengan pengetahuan awal yang telah dimilikinya kemudian membangun pengertian baru. Ibrahim dan Nur (2000) Vigotsky meyakini bahwa interaksi sosial dengan teman lain mengacu terbentuknya ide baru dan memperkaya perkembangan intelektual siswa. Kaitannya dengan Problem Based Instruction dalam hal mengaitkan informasi baru dengan struktur kognitif yang dimiliki oleh siswa melalui kegiatan belajar dalam interaksi sosial dengan teman lain Rusman (2012: 245). 


\section{Tujuan Problem Based Instruction}

Pembelajaran berbasis masalah tidak dirancang untuk membantu guru memberikan informasi sebanyakbanyaknya kepada siswa, tetapi lebih dimaksudkan untuk membantu siswa mengembangkan kemampuan berpikir, pemecahan masalah dan keterampilan intelektual.Menurut Rusman (2012: 238) mengemukakan tujuan pembelajaran berbasis masalah adalah penguasaan isi belajar pengembangan keterampilan pemecahan masalah. Pembelajaran berbasis masalah juga berhubungan dengan belajar tentang kehidupan yang lebih luas (lifewide learning), keterampilan memaknai informasi, kolaburatif dan belajar tim, keterampilan berpikir reflektif dan evaluatif.

Pendapat lain yaitu menurut Tan, Ibrahim dan Nur (2002), mengemukakan tujuan pembelajaran berbasis masalah secara lebih rinci, yaitu ; 1) membantu siswa mengembangkan kemampuan berpikir dan memecahkan masalah; 2) belajar berbagaiperanorangdewasamelaluipelibatanmerekadala mpengalamannyata; 3) menjadi para siswa yang otonom Rusman (2012: 239).

\section{Kelebihan dan Kekurangan Problem BasedInstruction}

Model pembelajaran Problem Based Instruction merupakan salah satu model pembelajaran yang dapat mengaktifkan siswanya dalam pembelajaran.Namun, model Problem Based Instruction ini pun tidak terlepas dari beberapa kelemahan selain juga berbagai kelebihannya. Berikut bebebapa kelemahan dan kelebihan model Problem Based Instruction.

Menurut Santoso (2011) beberapa kelemahan model Problem Based Instruction adalah sebagai berikut

\section{a. Membutuhkan waktu yang banyak;}

b. Membutuhkan fasilitas yang memadai seperti laboratorium, tempat duduk siswa yang terkondisi untuk belajar kelompok, perangkat pembelajaran,dll;

c. Menuntut guru membuat perencanaan pembelajaran yang lebihmatang;

d. Kurang efektif jika jumlah siswa terlalubanyak.

Sedangkan kelebihan Problem Based Instruction dalam Arends (2008: 45) sebagai suatu model pembelajaran antara lain :

a. Pembelajaran berbasis masalah mendorong kolaburasi dan penyelesaian bersama berbagaitugas;

b. Pembelajaran berbasis masalah memiliki elemenelemen yang mendorong observasi dan dialog dengan pihak lain agar seorang siswa mampu melaksanakanobservasi;

c. Pembelajaran berbasis masalah dapat melibatkan siswa dalam penelitian yang memungkinkan mereka untuk menjelaskan berbagai permasalahan nyata dan mengkontruksikan pemahaman merekasendiri;

d. Membantu siswa menjadi pembelajar yang independen dan belajar mandiri (self-regulated).

\section{Fungsi Media Pembelajaran}

Fungsi media pembelajaran selain sebagai alat untuk membantu dalam menyampaikan pesan juga untuk membantu siswa lebih mudah menerima pesan yang disampaikan. Pendapat Arsyad (2011: 15) mengemukakan bahwa pemakaian media pembelajaran dalam proses belajar mengajar dapat membangkitkan keinginan dan minat yang baru, membangkitkan motivasi dan rangsangan kegiatan belajar, dan membawa pengaruh yang psikologis terhadap siswa.

\section{Media Kartu Pintar}

Media kartu pintar atau dalam pembelajaran agama disebut sebagai lingkaran tajwid ini merupakan salah satu media berbasis cetakan. Media pembelajaran ini beguna untuk menyajikan penghafalan untuk materi yang disampaikan. Menurut pendapat Winanti (2009) kartu pintar merupakan alat permainan inovatif kreatif yaitu sesuatu yang digunakan untuk bermain, yang dapat mengaktifkan anak, yang dapat digunakan dalam proses pembelajaran. Kartu pintar yaitu karya guru atau anak terbuat dari kertas kartun, kertas bekas, kertas HVS, yang diberi gambar yang menarik yang dipadukan dengan permainan memasangkan huruf, kata, angka.Pintar yaitu pandai, cerdik dan mahir.Berdasarkan pengertian tersebut diatas permainan kartu pintar adalah permainan yang mengaktifkan anak untuk melatih kreativitasnya.

Penjelasan mengenai media cetakan juga disampaikan oleh Arsyad (2011: 87) media cetakan meliputi bahan-bahan yang disiapkan di atas kertas untuk pengajaran dan informasi. Media berbasis cetakan yang paling umum dikenal adalah buku teks, buku penuntun, jurnal, majalah, dan lembar lepas.

Format media kartu pintar berbasis cetakan ini adalah sebagai berikut :

a. Jika paragraf panjang sering digunakan, wajah satu kolom lebih sesuai, sebaliknya jika paragraf tulisan pendek-pendek, wajah dua kolom akan lebih sesuai.

b. Isi yang berbeda supaya dipisahkan dan dilabel secara visual

c. Taktik dan strategi pembelajaran yang berbeda sebaiknya dipisahkan dan dilabel secara visual.

\section{METODE PENELITIAN Jenis Penelitian}

Penelitian ini merupakan penelitian tindakan kelas, karena penelitian dilakukan untuk memecahkan masalah pembelajaran di kelas III SD Negeri 64/IV Kota Jambi.Penelitian ini juga termasuk penelitian deskriptif, sebab menggambarkan bagaimana suatu teknik pembelajaran pembelajaran diterapkan dan bagaimana hasil yang diinginkan dapat tercapai.Menurut sukidin dkk. (2002:54). Dengan demikian jenis penelitian yang digunakan peneliti adalah dalam bentuk PTK yang dilaksanakan sebanyak 3 Siklus apabila hasil pada siklus II lum mencapai keberhasilannya..Sedangkan bentuk tindakan yang dilakukan adalah guru sebagai peneliti dibantu oleh seorang observer sebagai penelitian tindakan kolaboratifnya.Penelitian ini mengacu pada perbaikan pembelajaran yang berkesinambungan.

\section{Lokasi dan Waktu Penelitian Lokasi Penelitian}


Lokasi penelitian tindakan kelas ini adalah SD Negeri 64/IV Kenali Besar Kecamatan Alam Berajo Kota Jambi.Penelitian ini dilakukan pada semester genap tahun pelajaran 2017/2018 yang berlokasi di Jalan Ir.H.Juanda, Rt. 33 Kelurahan Simpang III Sipin Kecamatan Kota Baru Kota Jambi.

\section{Waktu Penelitian}

Penelitian ini dilaksanakan selama 3 bulan yaitu dari bulan Januari sampai dengan bulan Maret 2018.

\section{Subjek Penelitian}

Subjek dalam penelitian ini adalah siswa kelas III SD Negeri 64 Kecamatan Kota Baru sebanyak 32 orang yang terdiri dari 17 siswa laki-laki dan 15 siswa perempuan. Penelitian dilakukan di kelas III karena peneliti adalah sebagai tenaga pengajar mata pelajaran IPA pada semester genap tahun pelajaran 2017/2018 dengan materi "Energi"

\section{Sumber Data Penelitian \\ Data Pengelolaan Pembelajaran Guru}

Data pengelolaan pembelajaran dalam menggunakan model pembelajaran Problem Based Instruction dengan media kartu pada setiap siklus pembelajaran IPA akan menggunakan lembar penilaian 1 , yaitu dengan lembar observasi yang digunakan oleh observer untuk menilai pengeloalan pembelajaran yang dilakukan oleh peneliti sebagai guru yang mengajar di kelas dalam penelitian tindakan kelas (PTK).

\section{Aktivitas belajar siswa.}

Data aktivitas belajar siswa dalam pembelajaran IPA pada setiap siklus pembelajaran akan menggunakan lembar observasi yang digunakan oleh observer untuk melakukan pengamatan siswa yang menerima materi pemeblajaran dengan menggunakan model pembelajaran Problem Based Instruction dengan media kartu.Data yang diperoleh kemudian diolah dengan menggunakan lembar penagamatn yang telah dibuat sesuai dengan aktivitas belajar siswa.

\section{Teknik Pengumpulan Data}

\section{Data Pengelolaan Pembelajaran Guru}

Teknik pengumpulan data tentang kinerja guru dalam menggunakan model pembelajaran Problem Based Instruction dengan media kartu dilakukan dengan cara mengisi lembar penilaian 1 yang dilakukan oleh pengamat lain selain peneliti pada saat proses pembelajaran pada setiap siklus.

\section{Data aktivitas belajar siswa}

Teknik pengumpulan data aktivitas belajar siswa dilakukan dengan cara mengisi lembar pengamatan 2 yang dilakukan oleh peneliti dan dibantu pengamat lain (selain peneliti) pada saat proses pembelajaran pada setiap siklus.

\section{Data Hasil Belajar Siswa}

Teknik pengumpulan data tentang hasil belajar siswa dilakukan dengan memberikan soal tes kemampuan siswa materi tentang Energi siswa sebanyak 5 soal dalam bentuk isian.

\section{Teknik Analisis data}

Teknik analisis data Pengelolaan Pebelajaran Guru.
Teknik analisis data kinerja guru dalam menggunakan model pembelajaran Problem Based Instruction dengan media kartu dilakukan dengan menggunakan teknik analisis kualitatif, karena data yang diperoleh berbentuk kategori/kualitatif. Teknik analisis data kinerja guru pada setiap siklus dilakukan dengan cara mengisi lembar pengamatan 1. Jumlah skor lembar penilaian 1 kemudian dipersentase dengan rumus sebagai berikut:

\begin{tabular}{|c|c|}
\hline & JSKG \\
\hline$\% \mathrm{KG}=$ & $\begin{array}{l}\mathrm{JSM} \\
\mathrm{JSM}\end{array}$ \\
\hline $\begin{array}{l}\text { Keterangan : } \\
\text { \%PG } \\
\text { JSPBG } \\
\text { JSM }\end{array}$ & $\begin{array}{l}\text { : Persentase Pengelolaan Pembeajaran guru. } \\
\text { : Jumlah skor Pengelolaan Pembelajaran Guru } \\
\text { : Jumlah skor maksimal }\end{array}$ \\
\hline
\end{tabular}

Selanjutnya dari hasil penghitungan rumus tersebut diklasifikasikan berdasarkan kategori pengelolaan pembelajaran guru yaitu sebagai berikut:

Tabel 1. Klasifikasi Persentase Pengelolaan Pembeajaran Guru

\begin{tabular}{ccc}
\hline No & Persentase & $\begin{array}{c}\text { Kategori Pengelolan Pembelajaran } \\
\text { Guru }\end{array}$ \\
\hline 1 & $1 \%-20 \%$ & Tidak baik \\
2 & $21 \%-41 \%$ & Kurang baik \\
3 & $41 \%-61 \%$ & Cukup \\
4 & $62 \%-82 \%$ & Baik \\
5 & $83 \%-100 \%$ & Sangat Baik \\
\hline
\end{tabular}

\section{Teknik analisis data aktivitas belajar siswa.}

Teknik analisis data aktivitas belajar siswa dalam pembelajaran PKn dilakukan dengan menggunakan teknik analisis kualitatif, karena data yang diperoleh berbentuk kategori/kualitatif. Teknik analisis data aktivitas belajar siswa pada setiap siklus dilakukan dengan cara mengisi lembar pengamatan 2 dan kemudian skornya dijumlah. Jumlah skor kemudian dipersentase dengan rumus sebagai berikut:

$$
\text { JSAS }
$$

\begin{tabular}{ll}
\cline { 2 - 2 }$\%$ AS $=$ & $\times 100$ \\
Keterangan : & JSM \\
$\%$ OS & : Persentase aktivitas belajar IPA \\
JSS & : Jumlah skor aktifitas belajar IPA \\
JSM & : Jumlah skor maksimal
\end{tabular}

Selanjutnya dari hasil penghitungan rumus tersebut diklasifikasikan berdasarkan kategori kinerja guru, yaitu sebagai berikut:

Tabel 2. Klasifikasi Persentase Aktivitas Siswa

\begin{tabular}{ccc}
\hline No & Persentase & Kategori Aktifitas Siswa \\
\hline 1 & $1 \%-24 \%$ & Tidak aktif \\
2 & $25 \%-50 \%$ & Kurang aktif \\
3 & $51 \%-75 \%$ & Aktif \\
4 & $76 \%-100 \%$ & Sangat aktif \\
\hline
\end{tabular}

\section{Teknik analisis data aktivitas belajar siswa.}

Teknik analisis data hasil belajar siswa dalam pembelajaran IPA dilakukan dengan peneliti melakukan penjumlahan nilai yang diperoleh peserta didik yang selanjutnya dibagi dengan jumlah peserta didik yang 
ada di kelas tersebut sehingga diperoleh rata-rata tes formatif dapat dirumuskan menggunakan teknik analisis kualitatif, karena data yang diperoleh berbentuk kategori/kualitatif. Jumlah skor kemudian dipersentase dengan rumus sebagai berikut:

\begin{tabular}{ccc}
\multicolumn{2}{c}{ Tabel } & 3.Klasifikasi Persentase Hasil Belajar Siswa \\
\hline No & Persentase & Kategori Hasil Nilai Belajar \\
\hline 1 & $90 \%-100 \%$ & Sangat Baik \\
2 & $79-89 \%$ & Baik \\
3 & $68 \%-78 \%$ & Cukup \\
4 & $59 \%-69 \%$ & Kurang \\
5 & $57 \%$ kebawah & Sangat Kurang \\
\hline
\end{tabular}

\section{HASIL DAN PEMBAHASAN \\ Gambaran Uum Lokasi Penelitian}

SD Negeri 64/IV kota Jambi mulai berdiri pada tahun 1977. Untuk memenuhi masyarakat sekitar akan adanya lembaga pendidikan dasar bagi putra dan putrid mereka dalam menuntut ilmu penegtahun. SD Negeri 64/IV Kota Jambi ini dibangun di atas tanah seluas 2063 $\mathrm{m}$ yang berlokasi di Ir.H.Juanda Rt. 33 Kelurahan Simpang III Sipin Kecamatan Kota Baru Kota Jambi. Keadaan sarana prasarana di SD Negeri 64/IV Kota Jambi masih kategori $90 \%$ Baik. Bahkan ruang kelas yang menjadi tempat melaksanakan proses pembelajaran berada pada kondisi yang layak untuk dipergunakan.

\section{Gambaran Umum Subjek Penelitian}

Gambaran umum subjek penelitian ini adalah siswa kelas III SD Negeri 64/IV Kota Jambi yang berjumlah sebanyak 32 orang yang terdiri dari 17 lakilaki dan 15 perempuan. Kondisi siswa sebelum dilakukan penelitian tindakan kelas bahwa hasil belajarnya dengan rata-rata ulangan hariannya sebesar 59,29

Walaupun hasil belajarnya belum maksimal ketika melakukan sebelum menggunakan model pembelajarn Problem Based Instruction dengan media kartu, namun untuk siswanya nya masih menunjukkan prestasi bidang akademik maupun non-akademik.SD $64 / \mathrm{IV}$ ini selalu meraih prestasi peringkat 8 besar dari 9 sekolah dasar yang ada di lingkungan pusat pembinaan pendidikan SD di Kecamatan Kota Baru Kota Jambi.

Berdasarkan hasil pengamatan peneliti sebagai guru yang mengajar, terlihat masih banyak peserta didik yang tidak memperhatikan ketika guru menerangkan pembelajaran didepan kelas serta kurangnya interaksi Tanya jawab antar peserta didik dan guru kelas. Hal ini tentunya berdampak pada hasil belajar peserta didik yang diperoleh dari tes ulangan harian.Data hasil ulangan harian tersebut dapat dilihat pada tabel di bawah ini.

Tabel 4. Hasil Nilai Ulangan Harian Pra Siklus

\begin{tabular}{|c|c|c|c|}
\hline No Urut & Nama & Nilai & Keterangan \\
\hline 1 & Adika Dwi Putra & 50 & Tidak tuntas \\
\hline 2 & Agnes Angriyanti & 60 & Tidak Tuntas \\
\hline 3 & Aldrian Candra Winata & 50 & Tidak tuntas \\
\hline 4 & Alfian Candra Winata & 70 & Tuntas \\
\hline 5 & Alya Natiqa Faradila & 65 & Tidak Tuntas \\
\hline 6 & Amabel Wyn Calista & 50 & Tidak tuntas \\
\hline 7 & Ananda Putra & 50 & Tidak tuntas \\
\hline 8 & Azma Permana Giza & 50 & Tidak tuntas \\
\hline 9 & Azzahra Aurel Desriana & 70 & Tuntas \\
\hline 10 & Azzahwa Aura Desriana & 55 & Tidak tuntas \\
\hline 11 & Chieka Ayudya Aulia & 60 & Tidak tuntas \\
\hline 12 & David Aglensius Sinaga & 60 & Tidak Tuntas \\
\hline 13 & Debora Charoline & 70 & Tuntas \\
\hline 14 & Ervan Dwi Saputra & 50 & Tidak tuntas \\
\hline 15 & Fadel Muhammad Athalah & 55 & Tidak tuntas \\
\hline 16 & Farelindo Siregar & 55 & Tidak tuntas \\
\hline 17 & Fani Karamoy & 70 & Tuntas \\
\hline 18 & Intan Putri Ramdhani & 70 & Tuntas \\
\hline 19 & Kezia Juni Marcelina & 75 & Tuntas \\
\hline 20 & Marisa Ayu & 60 & Tidak tuntas \\
\hline 21 & M. Dzaka Pandya Mahardika & 70 & Tuntas \\
\hline 22 & Meira Cantara & 65 & Tidak Tuntas \\
\hline 23 & Mikhael Ignatius & 70 & Tuntas \\
\hline 24 & M. Duwi prasetyo & 65 & Tuntas \\
\hline 25 & M. Jayandi alhafiz & 70 & Tuntas \\
\hline 26 & M. Raifan akbar & 60 & Tidak tuntas \\
\hline 27 & M. Reihan & 50 & Tidak tuntas \\
\hline 28 & M. Reza pratama & 60 & Tidak Tuntas \\
\hline 29 & Nabila Putri & 55 & Tidak Tuntas \\
\hline 30 & Naisyah Hanny & 65 & Tidak tuntas \\
\hline 31 & Putri Afni Aldania & 60 & Tidak Tuntas \\
\hline \multirow[t]{3}{*}{32} & Putri Indah Lestari & 60 & Tidak Tuntas \\
\hline & Jumlah Total & 1895 & \\
\hline & Rata - Rata Nilai Siswa & 59,29 & \\
\hline
\end{tabular}

Tabel 5. Rekapitulasi Hasil Ulangan Harian pada Pra Siklus

\begin{tabular}{lll}
\hline No & Uraian & Hasil \\
\hline 1 & Nilai rata-rata tes formatif & 59,29 \\
2 & Jumlah peserta didik yang tuntas belajar & 10 \\
3 & Perrsentase ketuntasan belajar & 31,25 \\
\hline
\end{tabular}

Berdasarkan tabel diatas dapat dijelaskan bahwa sebelum menerapkan model pembelajaran Problem Based Instruction dengan media kartu diperoleh nilai rata-rata hasil belajar peserta didik adalah 59,29 , dengan persentase ketuntasan belajar mencapai $31,25 \%$ atau ada 16 peserta didik dari 32 siswa.

\section{Siklus I}

Hasil penilain kinerja guru

Tabel 6. Hasil Observasi Penilaian Pengelolan Pembelajaran Guru Siklus I

\begin{tabular}{|c|c|c|c|c|c|}
\hline \multirow{2}{*}{ No } & \multirow{2}{*}{ Aspek kinerja guru yang dinilai } & \multicolumn{4}{|c|}{ Skor } \\
\hline & & 1 & 2 & 3 & 4 \\
\hline 1 & Menjelaskan tujuan pembelajaran & & & & \\
\hline 2 & Menjelaskan logistik yang dibutuhkan, & & & & \\
\hline 3 & Memotivasi siswa terlibat pada aktivitas pemecahan masalah. & & $\sqrt{ }$ & & \\
\hline 4 & $\begin{array}{l}\text { Membantu siswa untuk mendefinisikan dan mengorganisasikan tugas belajar yang berhubungan } \\
\text { dengan masalah tersebut. }\end{array}$ & & $\sqrt{ }$ & & \\
\hline 5 & Mendorong siswa untuk mengumpulkan informasi yang sesuai, & & $\sqrt{ }$ & & \\
\hline 6 & Melaksanakan eksperimen untuk mendapatkan penjelasan dan pemecahan masalah. & & & & \\
\hline 7 & Membantu siswa dalam merencanakan dan menyiapkan karya yang sesuai, seperti laporan, video, dan & & $\sqrt{ }$ & & \\
\hline
\end{tabular}



model serta membantu merekauntukberbagi tugas dengan temannya.
Membantu siswa untuk melakukan refleksi atau evaluasi terhadap penyelidikan mereka danproses-
proses yang mereka gunakan.

Jumlah Skor

Presentase Pengelolaan Pembelajaran Guru

Kategori Pengelolaan pembelajaran guru

Keterangan: (1) tidak baik, (2) kurang baik, (3) baik, (4) sangat baik
18

$56,25 \%$ Kurang baik

\section{Hasil Observasi aktivitas belajar siswa}

Tabel 7. Hasil Observasi Aktivitas Belajar Siswa Siklus I

\begin{tabular}{|c|c|c|c|c|}
\hline No & Nama Siswa & Skor & Persentase & Kategori Aktivitas \\
\hline 1 & Adika Dwi Putra & 13 & 54.2 & Aktif \\
\hline 2 & Agnes Angriyanti & 12 & 50.0 & Aktif \\
\hline 3 & Aldrian Candra Winata & 11 & 45.8 & Tidak Aktif \\
\hline 4 & Alfian Candra Winata & 15 & 62.5 & Aktif \\
\hline 5 & Alya Natiqa Faradila & 11 & 45.8 & Tidak Aktif \\
\hline 6 & Amabel Wyn Calista & 12 & 50.0 & Aktif \\
\hline 7 & Ananda Putra & 10 & 41.7 & Kurang Aktif \\
\hline 8 & Azma Permana Giza & 11 & 45.8 & Kurang Aktif \\
\hline 9 & Azzahra Aurel Desriana & 13 & 54.2 & Aktif \\
\hline 10 & Azzahwa Aura Desriana & 10 & 41.7 & Kurang Aktif \\
\hline 11 & Chieka Ayudya Aulia & 12 & 50.0 & Aktif \\
\hline 12 & David Aglensius Sinaga & 14 & 58.3 & Aktif \\
\hline 13 & Debora Charoline & 12 & 50.0 & Aktif \\
\hline 14 & Ervan Dwi Saputra & 11 & 45.8 & Tidak Aktif \\
\hline 15 & Fadel Muhammad Athalah & 13 & 54.2 & Aktif \\
\hline 16 & Farelindo Siregar & 14 & 58.3 & Aktif \\
\hline 17 & Fani Karamoy & 11 & 45.8 & Kurang Aktif \\
\hline 18 & Intan Putri Ramdhani & 11 & 45.8 & Kurang Aktif \\
\hline 19 & Kezia Juni Marcelina & 15 & 62.5 & Aktif \\
\hline 20 & Marisa Ayu & 13 & 54.2 & Aktif \\
\hline 21 & M. Dzaka Pandya Mahardika & 14 & 58.3 & Aktif \\
\hline 22 & Meira Cantara & 10 & 41.7 & Kurang Aktif \\
\hline 23 & Mikhael Ignatius & 11 & 45.8 & Kurang Aktif \\
\hline 24 & M. Duwi prasetyo & 15 & 62.5 & Aktif \\
\hline 25 & M. Jayandi alhafiz & 9 & 37.5 & Kurang Aktif \\
\hline 26 & M. Raifan akbar & 11 & 45.8 & Kurang Aktif \\
\hline 27 & M. Reihan & 12 & 50.0 & Aktif \\
\hline 28 & M. Reza pratama & 14 & 58.3 & Aktif \\
\hline 29 & Nabila Putri & 14 & 58.3 & Aktif \\
\hline 30 & Naisyah Hanny & 17 & 70.8 & Aktif \\
\hline 31 & Putri Afni Aldania & 10 & 41.7 & Tidak Aktif \\
\hline 32 & Putri Indah Lestari & 14 & 58.3 & Aktif \\
\hline \multirow{2}{*}{\multicolumn{3}{|c|}{$\begin{array}{l}\text { Jumlah siswa aktif/sangat aktif } \\
\text { Persentase siswa aktif/sangat aktif }\end{array}$}} & & 20 siswa \\
\hline & & & & $58,82 \%$ \\
\hline
\end{tabular}

Dari hasil penilaian pada aktivitas belajar siswa pada siklus I terdapat 20 siswa atau $58,82 \%$ siswa aktif mengikuti pembelajaran IPA dengan materi Energi. Dengan demikian penelitian pada siklus I belum memenuhi indikator keberhasilan, sehingga penelitian ini perlu dilanjutkan pada siklus berikutnya.

\section{Hasil Belajar Siswa Siklus I}

Tabel 8. Hasil Tes Belajar Siswa Siklus I

\begin{tabular}{llll}
\hline No & Nama & Nilai & Keterangan \\
\hline 1 & & & \\
2 & Adika Dwi Putra & 55 & Tidak tuntas \\
3 & Agnes Angriyanti & 70 & Tuntas \\
4 & Aldrian Candra Winata & 50 & Tidak tuntas \\
5 & Alfian Candra Winata & 70 & Tuntas \\
6 & Alya Natiqa Faradila & 70 & Tuntas \\
7 & Amabel Wyn Calista & 60 & Tidak tuntas \\
8 & Ananda Putra & 50 & Tidak tuntas \\
9 & Azma Permana Giza & 50 & Tidak tuntas \\
10 & Azzahra Aurel Desriana & 70 & Tuntas \\
11 & Chieka Ayudya Aulia & 60 & Tidak tuntas \\
12 & David Aglensius Sinaga & 60 & Tidak tuntas \\
13 & Debora Charoline & 60 & Tidak Tuntas \\
14 & Ervan Dwi Saputra & 50 & Tuntas \\
15 & Fadel Muhammad Athalah & 55 & Tidak tuntas \\
& & & Tidak tuntas
\end{tabular}

Farelindo Siregar

Fani Karamoy

Intan Putri Ramdhani

Kezia Juni Marcelina

Marisa Ayu

M. Dzaka Pandya Mahardika

Meira Cantara

Mikhael Ignatius

M. Duwi prasetyo

M. Jayandi alhafiz

M. Raifan akbar

M. Reihan

M. Reza pratama

Nabila Putri

Naisyah Hanny

Putri Afni Aldania

Putri Indah Lestari

Jumlah Total

Rata - Rata Nilai Siswa

$\begin{array}{ll}55 & \text { Tidak tuntas } \\ 70 & \text { Tuntas } \\ 75 & \text { Tuntas } \\ 75 & \text { Tuntas } \\ 60 & \text { Tidak tuntas } \\ 70 & \text { Tuntas } \\ 70 & \text { Tuntas } \\ 70 & \text { Tuntas } \\ 65 & \text { Tidak Tuntas } \\ 70 & \text { Tuntas } \\ 60 & \text { Tidak tuntas } \\ 50 & \text { Tidak tuntas } \\ 60 & \text { Tidak Tuntas } \\ 55 & \text { Tidak Tuntas } \\ 70 & \text { Tuntas } \\ 60 & \text { Tidak Tuntas } \\ 65 & \text { Tidak Tuntas } \\ 2000 & \\ 62,50 & \end{array}$

Tabel 9. Rekapitulasi Hasil Tes Belajar Siswa Siklus I

\begin{tabular}{lll}
\hline No & \multicolumn{1}{c}{ Uraian } & Hasil \\
\hline 1 & Nilai rata-rata tes formatif & 22,50 \\
2 & Jumlah peserta didik yang tuntas belajar & 13 \\
3 & Persentase ketuntasan belajar & 40,63 \\
\hline
\end{tabular}


Berdasarkan tabel diatas rekapitulasi hasil tes belajar siswa pada siklus I dapat dijelaskan bahwa sebelum menerapkan model pembelajaran Problem Based Instruction dengan media kartu diperoleh nilai rata-rata hasil belajar peserta didik adalah 22,50 dengan persentase ketuntasan belajar mencapai $40,63 \%$ atau ada 13 peserta didik dari 32 siswa.

\section{Siklus II}

Hasil penilaian pengelolaan pembelajaran guru

Tabel 10. Hasil Penilaian Pengelolaan Pembelajaran Guru Siklus II

\begin{tabular}{|c|c|c|c|c|c|}
\hline \multirow{2}{*}{ No } & \multirow{2}{*}{ Aspek kinerja guru yang dinilai } & \multicolumn{4}{|c|}{ Skor } \\
\hline & & 1 & 2 & 3 & 4 \\
\hline 1 & Menjelaskan tujuan pembelajaran & & & & $\sqrt{ }$ \\
\hline 2 & Menjelaskan logistik yang dibutuhkan, & & & & $\sqrt{ }$ \\
\hline 3 & Memotivasi siswa terlibat pada aktivitas pemecahan masalah. & & & $\sqrt{ }$ & \\
\hline 4 & $\begin{array}{l}\text { Membantu siswa untuk mendefinisikan dan mengorganisasikan tugas belajar yang berhubungan } \\
\text { dengan masalah tersebut. }\end{array}$ & & & $\sqrt{ }$ & \\
\hline 5 & Mendorong siswa untuk mengumpulkan informasi yang sesuai, & & $\sqrt{ }$ & & \\
\hline 6 & Melaksanakan eksperimen untuk mendapatkan penjelasan dan pemecahan masalah. & & $\sqrt{ }$ & & \\
\hline 7 & $\begin{array}{l}\text { Membantu siswa dalam merencanakan dan menyiapkan karya yang sesuai, seperti laporan, video, } \\
\text { dan model serta membantu merekauntukberbagi tugas dengan temannya. }\end{array}$ & & $\sqrt{ }$ & & \\
\hline 8 & $\begin{array}{l}\text { Membantu siswa untuk melakukan refleksi atau evaluasi terhadap penyelidikan mereka dan proses- } \\
\text { proses yang mereka gunakan. }\end{array}$ & & $\sqrt{ }$ & & \\
\hline Kateg & $\begin{array}{l}\text { Jumlah Skor } \\
\text { Presentase Pengelolaan Pembelajaaran Guru } \\
\text { pengelolaan pengolaan pembelajaran guru }\end{array}$ & & & & \\
\hline
\end{tabular}

Keterangan: (1) tidak baik, (2) kurang baik, (3) baik, (4) sangat baik

\section{Hasil Observasi aktivitas belajar siswa}

Tabel 11. Hasil Observasi Aktivitas Siswa Siklus II

\begin{tabular}{|c|c|c|c|c|}
\hline No & Nama Siswa & Skor & Persentase & Kategori Aktivitas \\
\hline 1 & Adika Dwi Putra & 16 & 66.7 & Aktif \\
\hline 2 & Agnes Angriyanti & 17 & 70.8 & Aktif \\
\hline 3 & Aldrian Candra Winata & 15 & 62.5 & Aktif \\
\hline 4 & Alfian Candra Winata & 19 & 79.2 & Aktif \\
\hline 5 & Alya Natiqa Faradila & 11 & 45.8 & Kurang Aktif \\
\hline 6 & Amabel Wyn Calista & 16 & 66.7 & Aktif \\
\hline 7 & Ananda Putra & 10 & 41.7 & Kurang Aktif \\
\hline 8 & Azma Permana Giza & 11 & 45.8 & Kurang Aktif \\
\hline 9 & Azzahra Aurel Desriana & 16 & 66.7 & Aktif \\
\hline 10 & Azzahwa Aura Desriana & 10 & 41.7 & Kurang Aktif \\
\hline 11 & Chieka Ayudya Aulia & 17 & 70.8 & Aktif \\
\hline 12 & David Aglensius Sinaga & 17 & 70.8 & Aktif \\
\hline 13 & Debora Charoline & 16 & 66.7 & Aktif \\
\hline 14 & Ervan Dwi Saputra & 11 & 45.8 & Kurang Aktif \\
\hline 15 & Fadel Muhammad Athalah & 17 & 70.8 & Aktif \\
\hline 16 & Farelindo Siregar & 14 & 58.3 & Aktif \\
\hline 17 & Fani Karamoy & 13 & 54.2 & Aktif \\
\hline 18 & Intan Putri Ramdhani & 11 & 45.8 & Kurang Aktif \\
\hline 19 & Kezia Juni Marcelina & 17 & 70.8 & Aktif \\
\hline 20 & Marisa Ayu & 17 & 70.8 & Aktif \\
\hline 21 & M. Dzaka Pandya Mahardika & 17 & 70.8 & Aktif \\
\hline 22 & Meira Cantara & 19 & 79.2 & Aktif \\
\hline 23 & Mikhael Ignatius & 15 & 62.5 & Aktif \\
\hline 24 & M. Duwi prasetyo & 15 & 62.5 & Aktif \\
\hline 25 & M. Jayandi alhafiz & 10 & 41.7 & Kurang Aktif \\
\hline 26 & M. Raifan akbar & 11 & 45.8 & Kurang Aktif \\
\hline 27 & M. Reihan & 15 & 62.5 & Aktif \\
\hline 28 & M. Reza pratama & 14 & 58.3 & Aktif \\
\hline 29 & Nabila Putri & 17 & 70.8 & Aktif \\
\hline 30 & Naisyah Hanny & 19 & 79.2 & Aktif \\
\hline 31 & Putri Afni Aldania & 10 & 41.7 & Kurang Aktif \\
\hline \multirow{2}{*}{32} & Putri Indah Lestari & 17 & 70.8 & Aktif \\
\hline & & gat aktif & & 21 \\
\hline
\end{tabular}

Dari hasil penilaian pada aktivitas belajar siswa pada siklus II terdapat 21 siswa atau $66,67 \%$ siswa aktif mengikuti pembelajaran pendidikan kewarganegaraan. Dengan demikian penelitian pada siklus II belum memenuhi indikator keberhasilan, sehingga penelitian ini perlu dilanjutkan pada siklus berikutnya.
Tabel 12. Hasil Tes Belajar Siswa Siklus II

\begin{tabular}{llll}
\hline No & Nama & Nilai & Keterangan \\
Urut & & & \\
\hline 1 & Adika Dwi Putra & 70 & Tuntas \\
2 & Agnes Angriyanti & 80 & Tuntas \\
3 & Aldrian Candra Winata & 70 & Tuntas \\
4 & Alfian Candra Winata & 75 & Tuntas \\
5 & Alya Natiqa Faradila & 80 & Tuntas
\end{tabular}




$\begin{array}{ll}6 & \text { Amabel Wyn Calista } \\ 7 & \text { Ananda Putra } \\ 8 & \text { Azma Permana Giza } \\ 9 & \text { Azzahra Aurel Desriana } \\ 10 & \text { Azzahwa Aura Desriana } \\ 11 & \text { Chieka Ayudya Aulia } \\ 12 & \text { David Aglensius Sinaga } \\ 13 & \text { Debora Charoline } \\ 14 & \text { Ervan Dwi Saputra } \\ 15 & \text { Fadel Muhammad Athalah } \\ 16 & \text { Farelindo Siregar } \\ 17 & \text { Fani Karamoy } \\ 18 & \text { Intan Putri Ramdhani } \\ 19 & \text { Kezia Juni Marcelina } \\ 20 & \text { Marisa Ayu } \\ 21 & \text { M. Dzaka Pandya Mahardika } \\ 22 & \text { Meira Cantara } \\ 23 & \text { Mikhael lgnatius } \\ 24 & \\ 25 & \text { M. Duwi prasetyo } \\ 26 & \text { M. Jayandi alhafiz } \\ 27 & \text { M. Raifan akbar } \\ 28 & \text { M. Reihan } \\ 29 & \text { M. Reza pratama } \\ 30 & \text { Nabila Putri } \\ & \text { Naisyah Hanny } \\ \end{array}$

$\begin{array}{ll}70 & \text { Tuntas } \\ 60 & \text { Tidak tuntas } \\ 60 & \text { Tidak tuntas } \\ 75 & \text { Tuntas } \\ 70 & \text { Tuntas } \\ 70 & \text { Tuntas } \\ 70 & \text { Tuntas } \\ 80 & \text { Tuntas } \\ 70 & \text { Tuntas } \\ 70 & \text { Tuntas } \\ 70 & \text { Tuntas } \\ 80 & \text { Tuntas } \\ 75 & \text { Tuntas } \\ 85 & \text { Tuntas } \\ 60 & \text { Tidak tuntas } \\ 75 & \text { Tuntas } \\ 70 & \text { Tuntas } \\ 70 & \text { Tuntas } \\ 65 & \text { Tidak } \\ & \text { Tuntas } \\ 70 & \text { Tuntas } \\ 60 & \text { Tidak tuntas } \\ 50 & \text { Tidak tuntas } \\ 60 & \text { Tidak } \\ 60 & \text { Tuntas } \\ 70 & \text { Tidak } \\ & \text { Tuntas } \\ & \text { Tuntas } \\ & \end{array}$

\begin{tabular}{cccl}
31 & & 60 & Tidak \\
32 & Putri Afni Aldania & 65 & $\begin{array}{l}\text { Tuntas } \\
\text { Tidak }\end{array}$ \\
& Putri Indah Lestari & & Tuntas \\
$\quad$ Jumlah Total & 2220 & \\
& Rata - Rata Nilai Siswa & 69,38 & \\
\hline
\end{tabular}

Table 13. Rekapitulasi Hasil Tes Belajar Siswa Siklus II

\begin{tabular}{lll}
\hline No & Uraian & Hasil \\
\hline 1 & Nilai rata-rata tes formatif & 69,38 \\
2 & Jumlah peserta didik yang tuntas belajar & 22 \\
3 & Persentase ketuntasan belajar & 68,75 \\
\hline
\end{tabular}

Berdasarkan tabel diatas yaitu rekapitulasi hasil tes belajar siswa dapat dijelaskan bahwa sebelum menerapkan model pembelajaran Problem Based Instruction dengan media kartu diperoleh nilai rata-rata hasil belajar peserta didik adalah 69,38, dengan persentase ketuntasan belajar mencapai 68,75\% atau ada 22 peserta didik dari 32 siswa.

\section{Siklus III}

Hasil penilaian pengelolaan pembelajaran guru

Tabel 14. Hasil Pengamatan dan Penilaian Pengelolaan pembelajaran guru Siklus III

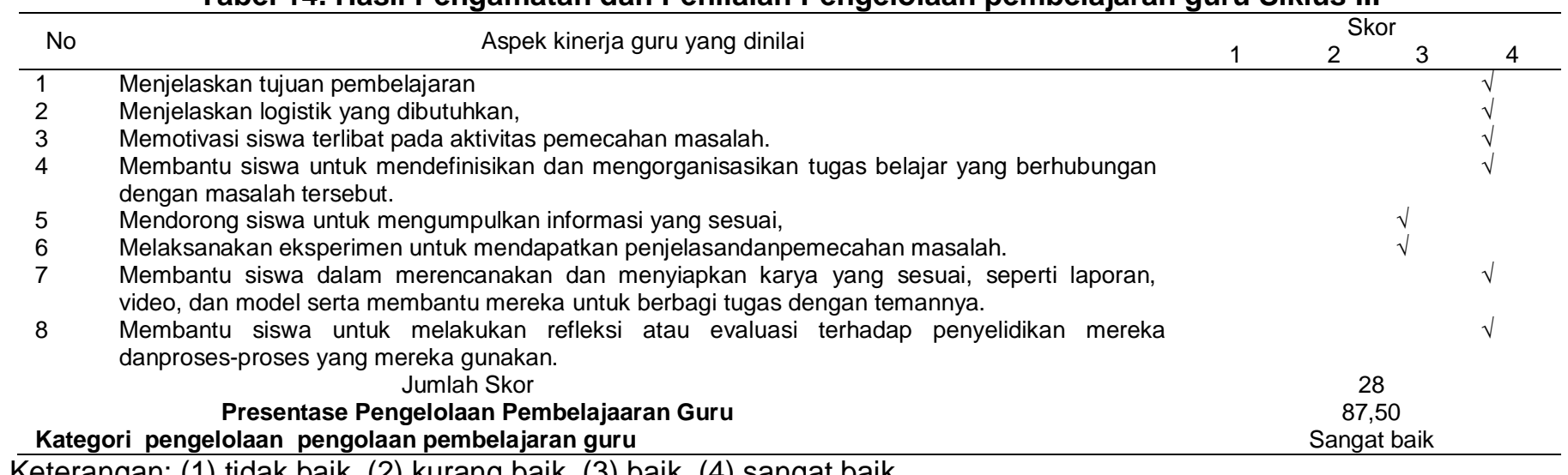

Keterangan: (1) tidak baik, (2) kurang baik, (3) baik, (4) sangat baik

Tabel 15. Hasil Observasi Aktivitas Belajar Siswa Siklus III

\begin{tabular}{|c|c|c|c|c|}
\hline No & Nama Siswa & Skor & Persentase & Kategori Aktivitas \\
\hline 1 & Adika Dwi Putra & 16 & 66.7 & Aktif \\
\hline 2 & Agnes Angriyanti & 17 & 70.8 & Aktif \\
\hline 3 & Aldrian Candra Winata & 21 & 87.5 & Aktif \\
\hline 4 & Alfian Candra Winata & 22 & 91.7 & Aktif \\
\hline 5 & Alya Natiqa Faradila & 11 & 45.8 & Kurang Aktif \\
\hline 6 & Amabel Wyn Calista & 20 & 83.3 & Aktif \\
\hline 7 & Ananda Putra & 10 & 41.7 & Kurang Aktif \\
\hline 8 & Azma Permana Giza & 11 & 45.8 & Kurang Aktif \\
\hline 9 & Azzahra Aurel Desriana & 22 & 91.7 & Aktif \\
\hline 10 & Azzahwa Aura Desriana & 10 & 41.7 & Kurang Aktif \\
\hline 11 & Chieka Ayudya Aulia & 21 & 87.5 & Aktif \\
\hline 12 & David Aglensius Sinaga & 23 & 95.8 & Aktif \\
\hline 13 & Debora Charoline & 20 & 83.3 & Aktif \\
\hline 14 & Ervan Dwi Saputra & 17 & 70.8 & Aktif \\
\hline 15 & Fadel Muhammad Athalah & 17 & 70.8 & Aktif \\
\hline 16 & Farelindo Siregar & 22 & 91.7 & Aktif \\
\hline 17 & Fani Karamoy & 19 & 79.2 & Aktif \\
\hline 18 & Intan Putri Ramdhani & 11 & 45.8 & Kurang Aktif \\
\hline 19 & Kezia Juni Marcelina & 17 & 70.8 & Aktif \\
\hline 20 & Marisa Ayu & 17 & 70.8 & Aktif \\
\hline 21 & M. Dzaka Pandya Mahardika & 17 & 70.8 & Aktif \\
\hline 22 & Meira Cantara & 19 & 79.2 & Aktif \\
\hline 23 & Mikhael Ignatius & 15 & 62.5 & Aktif \\
\hline 24 & M. Duwi prasetyo & 18 & 75.0 & Aktif \\
\hline 25 & M. Jayandi alhafiz & 16 & 66.7 & Aktif \\
\hline 26 & M. Raifan akbar & 11 & 45.8 & Kurang Aktif \\
\hline
\end{tabular}




$\begin{array}{ll}27 & \text { M. Reihan } \\ 28 & \text { M. Reza pratama } \\ 29 & \text { Nabila Putri } \\ 30 & \text { Naisyah Hanny } \\ 31 & \text { Putri Afni Aldania } \\ 32 & \text { Putri Indah Lestari }\end{array}$

Dari hasil penilaian pada aktivitas belajar siswa pada siklus III terdapat 27 siswa atau 79,41\% siswa aktif mengikuti pembelajaran IPA dengan materi Energi. Dengan demikian penelitian pada siklus III sudah memenuhi indikator keberhasilan, sehingga penelitian ini tidak perlu dilanjutkan pada siklus berikutnya untuk kegiatan aktivitas siswa. Karena hasil pengelolaan pembelajaran guru dan aktivitas sudah baik pada siklus 2 dan 3 , maka hasil belajr siswa akan lebih baik lagi ayitu kaetegori sangat baik. Untuk itu dapat diliaht pada tabel berikut untuk hasil belajar siswa siklus III.

\section{Hasil Belajar Siklus III}

Tabel 16. Hasil Tes Belajar Siswa Siklus III

\begin{tabular}{|c|c|c|c|}
\hline $\begin{array}{l}\text { No } \\
\text { Urut }\end{array}$ & Nama & Nilai & Keterangan \\
\hline 1 & Adika Dwi Putra & 70 & Tuntas \\
\hline 2 & Agnes Angriyanti & 80 & Tuntas \\
\hline 3 & Aldrian Candra Winata & 70 & Tuntas \\
\hline 4 & Alfian Candra Winata & 90 & Tuntas \\
\hline 5 & Alya Natiqa Faradila & 90 & Tuntas \\
\hline 6 & Amabel Wyn Calista & 85 & Tuntas \\
\hline 7 & Ananda Putra & 90 & Tuntas \\
\hline 8 & Azma Permana Giza & 80 & Tuntas \\
\hline 9 & Azzahra Aurel Desriana & 90 & Tuntas \\
\hline 10 & Azzahwa Aura Desriana & 90 & Tuntas \\
\hline 11 & Chieka Ayudya Aulia & 75 & Tuntas \\
\hline 12 & David Aglensius Sinaga & 85 & Tuntas \\
\hline 13 & Debora Charoline & 90 & Tuntas \\
\hline 14 & Ervan Dwi Saputra & 60 & Tidak tuntas \\
\hline 15 & Fadel Muhammad Athalah & 90 & Tuntas \\
\hline 16 & Farelindo Siregar & 65 & Tidak tuntas \\
\hline 17 & Fani Karamoy & 90 & Tuntas \\
\hline 18 & Intan Putri Ramdhani & 90 & Tuntas \\
\hline 19 & Kezia Juni Marcelina & 85 & Tuntas \\
\hline 20 & Marisa Ayu & 80 & Tuntas \\
\hline 21 & M. Dzaka Pandya Mahardika & 80 & Tuntas \\
\hline 22 & Meira Cantara & 80 & Tuntas \\
\hline 23 & Mikhael Ignatius & 85 & Tuntas \\
\hline 24 & M. Duwi prasetyo & 80 & Tuntas \\
\hline 25 & M. Jayandi alhafiz & 90 & Tuntas \\
\hline 26 & M. Raifan akbar & 85 & Tuntas \\
\hline 27 & M. Reihan & 60 & Tidak tuntas \\
\hline 28 & M. Reza pratama & 70 & Tuntas \\
\hline 29 & Nabila Putri & 80 & Tuntas \\
\hline 30 & Naisyah Hanny & 80 & Tuntas \\
\hline 31 & Putri Afni Aldania & 90 & Tuntas \\
\hline \multirow[t]{3}{*}{32} & Putri Indah Lestari & 80 & Tuntas \\
\hline & Jumlah Total & 2605 & \\
\hline & Rata - Rata Nilai Siswa & 81,41 & \\
\hline
\end{tabular}

Tabel 17. Rekapitulasi Hasil Tes Belajar Siswa Siklus III

\begin{tabular}{llc}
\hline No. & Uraian & Hasil \\
\hline 1 & Nilai rata-rata tes formatif & 81,91 \\
2 & Jumlah peserta didik yang tuntas belajar & 29 \\
3 & Persentase ketuntasan belajar & 90,63 \\
\hline
\end{tabular}

Berdasarkan tabel diatas rekapitulasi hasil tes belajar siswa pada siklus III dapat dijelaskan bahwa sebelum menerapkan model pembelajaran Problem Based Instruction dengan media kartu diperoleh nilai rata-rata hasil belajar peserta didik adalah 81,91, dengan persentase ketuntasan belajar mencapai $90,63 \%$ atau ada 29 peserta didik dari 32 siswa.Dengan demikian karena hasil belajarnya siswa kelas III sudah mengalami peningkatan baik dari ratarata maupun ketuntasan belajarnya, maka peneltian ini hanya sampai siklus III.

Berdasarkan hasil penelitian yang dilakukan pada siklsu I sampai dengan siklus III, maka dapat dilihat perbandingan hasil dari pengelolaan pembelajaran guru, aktivitas belajar, dan hasil belajar siswa menunjukkan adanya peningkatan sangat signifikan. Untuk itu dapat dilihat tabel berikut:

Tabel 18. Rekapitulasi Perbandingan Nilai Observasi Kinerja Guru, aktivitas siswa dan hasil belajar siswa siklus I, II, dan III

\begin{tabular}{clccc}
\hline No. & Hasil Penelitian & Siklus I & Siklus II & Siklus III \\
\hline 1. & Pengelolaan Guru & 56,25 & 68,75 & 87,50 \\
2. & Aktivitas Siswa & 58,82 & 66,67 & 79,41 \\
3. & Hasil belajar & 62,50 & 69,38 & 81,41 \\
\hline
\end{tabular}

Berdasarkan tabel diatas menunjuk bahwa dari rekapitulasi perbandingan nilai obersevasi pengelolaan pembelajaran, aktivitas siswa dan hasil belajara mulai dari siklus I sampai dengan siklus II adanya peningkatan aktivitas dan hasil belajar siswa dalam menggunakan model pembelajaranProblem Based Instruction dengan media kartu kelas III SD Negeri 64/IV Simpang III Sipin Kecamatan Kota Baru Kota Jambi. Dengan demikian hasil perbandingan tersebut dapat dilihat pada grafik 1 di bawah ini.

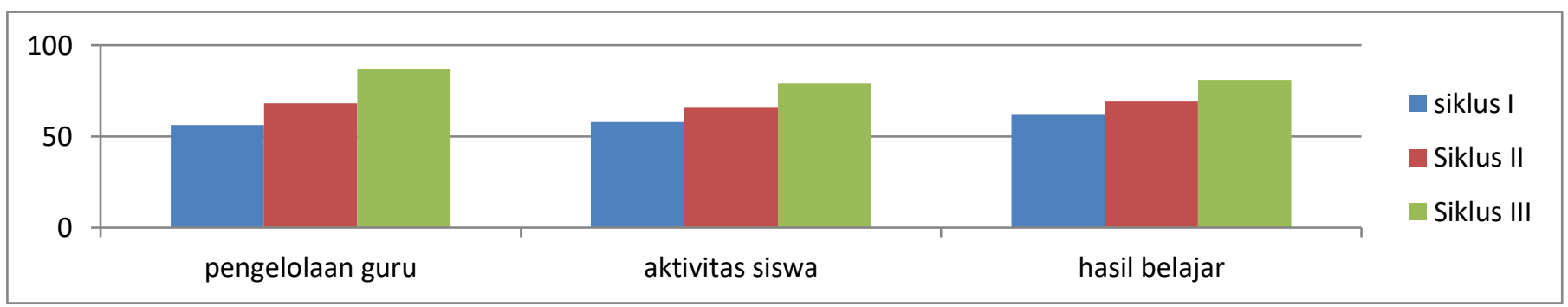

Grafik 1. Rekapitulasi Perbandingan Hasil Penelitian Siklus I, II, dan III 


\section{Pembahasan \\ Siklus I}

Hasil penilaian pada pengelolaan pembelajaran guru dalam menggunakan model pembelajaran Problem Based Instruction dengan media kartu adalah 62,50\% dengan kategori baik. Sedangkan aktivitas belajar siswa dalam mengikuti pembelajaran IPA terdapat 20 siswa atau $66,67 \%$. Dengan demikian penelitian pada siklus I belum memenuhi indikator keberhasilan. Hal ini desebabkan karena adanya kelemahan/ kekurangan pengelolaan pembelajaran guru dalam menggunakan model pembelajaran Problem Based Instruction dengan media kartupada siklus I, yaitu sebagai berikut:

a) Guru kurang membantu siswa untuk mendefinisikan dan mengorganisasikan tugas belajar yang berhubungan dengan masalah tersebut.

b) Guru kurang memotivasi siswa

c) Guru kurang membantu siswa untuk mendefinisikan dan mengorganisasikan tugas belajar yang berhubungan dengan masalah tersebut.

d) Guru kurang melaksanakan eksperimen untuk mendapatkan penjelasan dan pemecahan masalah

e) Membantu siswa dalam merencanakan dan menyiapkan karya yang sesuai, seperti laporan, video, dan model serta membantu merekauntukberbagi tugas dengan temannya

f) Guru kurang membantu siswa untuk melakukan refleksi atau evaluasi terhadap penyelidikan mereka dan proses-proses yang mereka gunakan.

\section{Siklus II}

Untuk mengatasi kekurangan dan kelemahan kinerja guru dalam menggunakan model pembelajaran Problem Based Instruction dengan media kartu pada siklus I, maka telah diadakan perbaikan-perbaikan kinerja guru, yaitu sebagai berikut:

a) Guru kurang membantu siswa untuk mendefinisikan dan mengorganisasikan tugas belajar yang berhubungan dengan masalah tersebut.

b) Guru kurang melaksanakan eksperimen untuk mendapatkan penjelasan dan pemecahan masalah

c) Membantu siswa dalam merencanakan dan menyiapkan karya yang sesuai, seperti laporan, video, dan model serta membantu mereka untuk berbagi tugas dengan temannya

d) Guru kurang membantu siswa untuk melakukan refleksi atau evaluasi terhadap penyelidikan mereka danproses-proses yang mereka gunakan.

Dari upaya perbaikan-perbaikan pengelolaan pembelajaaran guru dalam penggunaan model pembelajaran Problem Based Instruction dengan media kartu pada siklus II maka diperoleh peningkatan pengelolaan pembelajaaran guru yaitu dari $62,50 \%$ menjadi $75,00 \%$ dengan kategori baik. Hal ini berpengaruh pula terhadap peningkatan aktivitas belajar siswa dalam pembelajaran IPA yaitu dari siklus I (58,82\% menjadi $66,67 \%$. Dengan demikian penelitian pada siklus II belum memenuhi indikator keberhasilan. Hal ini desebabkan karena adanya kelemahan/kekurangan pada kinerja guru dalam menggunakan model pembelajaran Problem Based Instruction dengan media kartu, yaitu sebagai berikut: a. Guru kurang mahir dalam mengeksplorasi gagasan untuk memunculkankonsepsi awal siswa

b. Guru kurang mampu dalam mengarahkan siswa untuk menjawab pertanyaan yang disusun untuk menerapkan konsep ilmiah yang telah dikembangkan siswa ke dalam situasi baru

\section{Siklus III}

Untuk mengatasi kekurangan dan kelemahan kinerja guru dalam menggunakan Problem Based Instruction dengan media kartupada siklus II, maka perlu diadakan perbaikan-perbaikan kinerja guru, yaitu sebagai berikut:

a. Guru berusaha meningkatkan kemahiran dalam memunculkan dan mengeksplorasi gagasan untuk memunculkan konsepsi awal siswa.

b. Guru harus meingkatkan kemampua dalam mengarahkan siswa untukmenjawab pertanyaan yang disusun untuk menerapkan konsep ilmiah yang telah dikembangkan siswa ke dalam situasi baru.

Berdasarkan dari upaya perbaikan-perbaikan kinerja guru dalam penggunaan model pembelajaran Problem Based Instruction dengan media kartupada siklus III maka diperoleh peningkatan pengelolaan pembelajaarn guru yaitu $87,50 \%$ dengan kategoriSangat baik. Hal ini berpengaruh pula terhadap peningkatan aktivitas belajar siswa dalam pembelajaran IPA yaitu dari $66,67 \%$ menjadi $79,41 \%$. Selanjutnya akan berdambak lagi pada hasil belajar yaitu Dengan demikian penelitian pada siklus III sudah memenuhi indikator keberhasilan. Hal ini berarti penelitian ini tidak perlu dilanjutkan pada siklus berikutnya

\section{SIMPULAN}

1. Pembelajaran model Problem Based Instruction dengan media kartu menekankan terbangunnya pemahaman sendiri secara aktif, kreatif dan produktif berdasarkan pengetahuan terdahulu.dan pengalaman belajar yang bermakna.

2. Dengan menggunakan model pembelajaranProblem Based Instruction dengan media kartupada proses pembelajaran IPA dengan materi Energi dapat meningkatkan aktivitas belajarsiswa.

3. Semakin meningkatpengelolaan pembelajaarn guru dalam menggunakan model pembelajaran model Problem Based Instruction dengan media kartudalam pembelajaran IPA dengan materi Energi, makasemakin meningkat aktivitas belajar siswa. Hal ini dapat terlihat dari hasil penelitian pada siswa kelas III SD Negeri 64/IV Simpang III Sipin Kecamatan Kota Baru Kota Jambi, yaitu sebagai berikut: Pada siklus I pengelolaan pembelajaarn guru mencapai $56,25 \%$, aktivitas belajar siswa mencapai $58,82 \%$ dan hasil belajar adalah 62,50 . Pada siklus II pengelolaan pembelajaarn guru mencapai $68,75 \%$ dan aktivitas belajar siswa mencapai 66,67\% selanjutnya hasil belajar siswa 69,38. Pada siklus III kinerja guru mencapai $87,50 \%$ dan aktivitas belajar siswa mencapai $79,41 \%$ selanjutnya hasil belajar 81,41 . 


\section{DAFTAR PUSTAKA}

Anni, Catharina Tri, dkk. 2006. Motivasi Belajar. Semarang: UPT UNNES

Aqib, Zainal, dkk. 2011. Penelitian Tindakan Kelas Untuk Guru SD,SLB, TK. Bandung: CV. Yrama Widya

Arends, I. Richard.2008. Learning To Teach (Belajar untuk Mengajar). Yogyakarta: Pustaka Pelajar

Arikunto, Suharsimi. 2006. Prosedur Penelitian Suatu Pendekatan Praktik. Jakarta: PT Rineka Cipta 2008. Penelitian Tindakan Kelas. Jakarta: Bumi Aksara

Arsyad, Azhar. 2011. Media Pembelajaran. Jakarta: PT Raja Grafindo Persada Badan Standar Satuan Pendidikan

(BSNP). 2007. Standar Proses. Jakarta: Badan Standar Satuan Pendidikan.

Cakudik. 2012. Revisi Taksonomi Bloom.

Depdiknas. 2004. Kualitas Pembelajaran. Jakarta: Departemen Pendidikan Nasional.

2007. Kajian Kebijakan Kurikulum Mata Pelajaran IPA. Jakarta : Pusat Kurikulum Balitbang Depdiknas.

Fatthurrohman, Pupuh, Sobry Sutikno. 2001. Strategi Belajar Mengajar Melalui Penanaman Konsep Umum dan Konsep Islami. Bandung: CV Maulana

Gunanto, Muhammad Okto. 2012. Peningkatan Kualitas Pembelajaran IPA Melalui Model Pembelajaran Problem Based Instrction pada Kelas IVB SD Negeri Tambakaji 01 Semarang. Skripsi: UNNES

Hakim, Luqman. 2012. Jurnal Pendidikan dengan Model Problem Based Instruction. Tersedia pada : [online]

http://journal.uns.ac.id/index.php/diunduhpada Februari 2013 pukul 09.01

Hamalik, Oemar. 2008. Proses Belajar Mengajar. Jakarta: Sinar Grafika

Hamdani. 2011. Strategi Belajar Mengajar. Bandung: CV. Pustaka Setia

Herrhyanto, Nar dan H.M. Akib Hamid. 2007. Statistika Dasar. Jakarta: Universitas Terbuka

Indriana, Dina. 2011. Ragam Alat Bantu Media Pengajaran. Jogjakarta: DIVA Press

Iwan.2012. Media Kartu Pintar. Tersedia pada: [online] http://iwansmtri.blogspot.com/2012/09/belajarmatematika-dengan-kartu-kemudi.html. diunduh pada 1 Februari 2013 pukul 10.11

Wardani, I.G.A.K. 2008.Strategi Belajar Mengajar. Jakarta: Departemen Pendidikan Nasional.

Khoi.2009. Berbagai Kriteria Guru Efektif. Tersedia pada: [online] http://khoi82.wordpress.com. diunduh pada 28 Mei 2013 pukul 09.03

Lapono, Nabisi, dkk. 2008. Belajar Pembelajaran. Jakarta: Depdiknas

Labolatorium Pengembangan Pendidikan dan Pembelajaran Islam (LP3I). 2010.

Keterampilan Dasar Mengajar. Jogjakarta: Ar-Ruzz Media

Nasution, Noehi, dkk.1999. Pendidikan IPA di SD. Jakarta: Universitas Terbuka Poerwanti, Endang. 2008. Asesmen Pembelajaran.Jakata: Depdiknas

Permendiknas. 2007. Standar Proses Untuk Satuan Pendidikan Dasar dan Menengah. Tersedia pada: [online]

akhmadsudrajat.files.wordpress.com/2009/04/stan dar-proses-_permen-41- 2007_.pdf PERMENDIKNAS NO 41 TAHUN 2007 diunduh pada 2 Juli 2013 pukul 13.41

Redaksi. 2012. Kartu Pintar Pada Pembelajaran IPA. Tersedia pada: [online] KORANPENDIDIKAN.com diunduh pada 6 Juli 2013 pukul 07.07

Rifa"i, Achmad, Catharina Tri Anni. 2009. Psikologi Pendidikan. Semarang: UPT UNNES Press

Rusman. 2012. Model-Model Pembelajaran Mengembangkan Profesionalisme Guru. Jakarta: PT Grafindo Persada

Santoso, Eko. Budi. 2011. Kelemahan Model Pembelajaran Problem Based Instruction. Tersedia pada : [online] http://ras-

eko.blogspot.com/favicon.ico diunduh 30 Desember 2012 pukul 12.37 Sardiman. 2012. Interaksi dan Motivasi Belajar Mengajar. Jakarta: Rajawali Pers

Slavin, Robert. E. 1994. Educational Psycholog Theory and Practise.Massachuettes United States of America: A Division of Paramount Publishing.

Sudjana, Nana. 1989. Penilaian Hasil Proses Belajar Mengajar.Bandung: PT. Remaja Rosdakarya

Suharti, Eny. 2012. Kartu Pintar.

Sukmadinata. 2009. Metode Penelitian Pendidikan. Bandung: PT. Remaja Rosdakarya

Suprijono, Agus. 2009. Cooperative Learning. Yogyakarta: Pustaka Pelajar Sutama. 2011. Metode Penelitian Pendidikan Kuantatif, Kualitatif, $P T K, R \& D$.

Surakarta: Fairuz Media

Sutrisno, Leo, dkk. 2007.Pengembangan Pembelajaran IPA SD. Jakarta: Depdiknas

Trianto. 2010. Model Pembelajaran Terpadu. Jakarta: Bumi Aksara Undang-Undang Permendiknas No 22 Tahun 2006 tentang Standar Isi.

Wahyudin. 2008. Pengantar Pendidikan. Jakarta: Universitas Terbuka. Warpala, Sukra I Wayan. 2012. Teori Vygotsky. 